\title{
Efektivitas Ekstrak Bunga Melati (Jasminum Sambac L.) Terhadap Kematian Larva Aedes Aegypty
}

\section{Effectiveness of Jasmine Flower Extract (Jasminum Sambac L.) Against The Death of Aedes Aegypty Larvae}

\author{
Munadia Husna*1, Ratna Sari Dewi ${ }^{2}$, Eko Mirsiyanto ${ }^{3}$ \\ ${ }^{1,2,3}$ Sekolah Tinggi Ilmu Kesehatan Harapa Ibu Jambi, Jambi \\ *Korespondensi Penulis: ${ }^{1}$ munadiahusna01@ gmail.com
}

\begin{abstract}
ABSTRAK
Larva nyamuk Aedes aegypti berperan dalam vektor penularan penyakit Dengue Hemorhagic Fever (DHF). Untuk memutus rantai penularan penyakit, maka larva sebagai rantai dari perkembangan nyamuk perlu diberantas atau dikendalikan. Tujuan penelitian ini adalah untuk mengetahui efektivitas minyak atsiri bunga melati (Jasminum sambac (L.)ait) terhadap daya bunuh larva nyamuk. Metode dalam penelitian ini menggunakan desain Quasi eksperimen dengan Post test Only Control Group. Sampel yang di gunakan yaitu larva Aedes Aegypti dan pada setiap perlakuan dberikan sebanyak 20 larva dengan 5 kali pengulangan, sehingga jumlah seluruh larva yang di butuhkan yaitu 700 larva. Hasil penelitian menunjukkan bahwa ekstrak bunga melati efektif terhadap kematian larva Aedes aegypti dalam waktu 24 jam. Nilai signifikan $\mathrm{p}=0,000(\mathrm{p}<0,05)$ ada hubungan antara jumlah kematian larva dengan konsentrasi ekstrak bunga melati. Jadi dapat di simpulkan bahwa rata-rata jumlah larva Aedes aegypti yang mati untuk setiap konsentrasi mengalami peningkatan, semakin besar konsentrasi yang di pakai untuk perlakuan semakin banyak jumlah larva yang mati. Selain itu juga, yang menunjukkan efektif adalah $0,05 \%$, karena konsentrasi $0,05 \%$ sudah dapat membunuh larva Aedes aegypti $100 \%$ dalam waktu 24 jam.
\end{abstract}

\section{Kata Kunci : Aedes aegypti, bunga melati, ekstrak, larvasida}

\begin{abstract}
Aedes aegypti mosquito larvae play a role in the vector of dengue hemorrhagic fever (DHF) transmission. To break the chain of disease transmission, larvae as the chain of mosquito development need to be eradicated or controlled. The purpose of this study was to determine the effectiveness of jasmine (Jasminum sambac (L.) ait) essential oil on the killing power of mosquito larvae. The method in this study used a Quasi-experimental design with Post test Only Control Group. The samples used were Aedes Aegypti larvae and in each treatment 20 larvae were given with 5 repetitions, so that the total number of larvae needed was 700 larvae. The results showed that jasmine flower extract was effective against the death of Aedes aegypti larvae within 24 hours. A significant value of $p=0.000$ ( $p$ $<0.05)$ there is a relationship between the number of larvae deaths and the concentration of jasmine flower extract. So it can be concluded that the average
\end{abstract}


Journal of Healthcare Technology and Medicine Vol. 6 No. 2 Oktober 2020

Universitas Ubudiyah Indonesia

e-ISSN : 2615-109X

number of dead Aedes aegypti larvae for each concentration has increased, the greater the concentration used for treatment the greater the number of dead larvae. In addition, what shows effectiveness is $0.05 \%$, because a concentration of $0.05 \%$ can kill 100\% Aedes aegypti larvae within 24 hours.

\section{Keywords: Aedes aegypti, jasmine flower, extract, larvicide}

\section{PENDAHULUAN}

Menurut data WHO (2014) Penyakit demam berdarah dengue pertama kali dilaporkan di Asia Tenggara pada tahun 1954 yaitu di Filipina, selanjutnya menyebar keberbagai negara. Sebelum tahun 1970, hanya 9 negara yang mengalami wabah DBD, namun sekarang DBD menjadi penyakit endemik pada lebih dari 100 negara, diantaranya adalah Afrika, Amerika, Mediterania Timur, Asia Tenggara dan Pasifik Barat memiliki angka tertinggi terjadinya kasus DBD. Jumlah kasus di Amerika, Asia Tenggara dan Pasifik Barat telah melewati 1,2 juta kasus ditahun 2008 dan lebih dari 2,3 juta kasus di 2010. Pada tahun 2013 dilaporkan terdapat sebanyak 2,35 juta kasus di Amerika, dimana 37.687 kasus merupakan DBD berat. Perkembangan kasus DBD di tingkat global semakin meningkat, seperti dilaporkan Organisasi Kesehatan Dunia (WHO) yakni dari 980 kasus di hampir 100 negara tahun 1954-1959 menjadi 1.016.612 kasus di hampir 60 negara tahun 2000-2009.

Kemenkes RI (2019) mencatat 29 januari 2019 jumlah kasus DBD mencapai 13.683 dengan jumlah meninggal dunia sebanyak 133 jiwa. Kasus DBD terus bertambah secara nasional, jumlah kasus hingga tanggal 3 februari 2019 adalah sebanyak 16.692 kasus dengan 169 meninggal dunia. Kasus terbanyak ada di wilayah Jawa Timur, Jawa Tengah, NTT, dan Kupang.

Berdasarkan data dari Dinas Kesehatan Kota Jambi menyatakan sepanjang tahun 2018 ditemukan sebanyak 220 kasus Demam Berdarah Dengue (DBD) yang menyerang warga dan 1 orang meninggal dunia. Dari data Pengendalian dan Pemberantasan Penyakit Menular (P2M) Dinas Kesehatan Kota Jambi untuk kasus DBD tahun 2019 ditemukan sebanyak 220 kasus, Kecamatan Telanai Pura 13 kasus, Jambi Timur 16 kasus, Jambi Selatan 17 kasus, Danau Teluk 4 kasus, Pelayangan 4 kasus, Pasar Jambi 6 kasus, Kota Baru 28 kasus, Jelutung 18 kasus, 
Journal of Healthcare Technology and Medicine Vol. 6 No. 2 Oktober 2020

Universitas Ubudiyah Indonesia

e-ISSN : 2615-109X

Danau Sipin 39 kasus dan 1 orang meninggal, Paal Merah 30 kasus, dan Alam Barajo 45 kasus.

Langkah-langkah untuk mengendalikan penyakit demam berdarah pada dasarnya merupakan pengurangan terhadap populasi vector yang biasanya dilakukan pada stadium dewasa dan larva, tetapi pengendalian nyamuk lebih mudah pada stadium larva. Karena pada stadium ini gerak dan aktivitasnya masih di dalam air dan terbatas. Pengendalian pada stadium larva yang dilakukan dengan abatisasi secara terus menerus dapat menimbulkan resistensi pada larva Aedes aegypti, maka perlu dilakukan alternative lain selain bahan kimia, yang lebih aman untuk mencegah perkembangan larva Aedes aegypti. Salah satu alternative yang digunakan dengan menggunakan tanaman yang mengandung senyawasenyawa aktif yang bersifat toksik sebagai larvasida. Pemakakain minyak atsiri dari bagian tumbuhan yang mempunyai kandungan senyawa-senyawa aktif yang bersifat toksik digunakan karena dapat memperkecil tingkat populasi dan mengurangi resiko terhadap kesehatan (Lyaningsih, 2004).

Penggunaan insektisida alami di Indonesia dapat menjadi pilihan tepat, karena Indonesia memiliki beranekaragam tumbuhan yang berpotensi sebagai insektisida alami. Salah satu tumbuhan yang dapat digunakan sebagai insektisida alami yaitu bunga melati (Jasminum sambac L.). Tanaman bunga melati (Jasminum sambac L.) memiliki kandungan senyawa kimia yaitu yaitu methyl salisilat, cis jasmine, linalool, neurol idol dan indole yang dapat digunakan sebagai larvasida alami (Sumantri, 2010).

Hasil penelitian Nurdianti, Desti (2014) di Surakarta. Ia melakukan Uji Keefektifan Daya Bunuh Minyak Atsiri Bunga Kenanga (Cannangium odoratum) Terhadap Kematian Larva Nyamuk Aedes aegypti Instar III. Yang diamati selama 24 jam dengan menggunakan hewan percobaan 25 ekor maka di dapatkan hasil Efektivitas ekstrak dalam membunuh larva nyamuk Aedes aegypti pada konsentrasi $0,055 \%$ terjadi kematian larva 18 ekor (72\%), konsentrasi 0,065\% sebanyak 23 ekor (89\%), konsentrasi 0,075\% sebanyak 25 ekor (100\%), dan konsentrasi 0,085\% sebanyak 25 ekor (100\%). Jadi dalam membunuh larva nyamuk Aedes Aegypti adalah konsentrasi 0,075 \% yang merupakan konsentrasi terkecil yang sudah dapat membunuh larva sebanyak 1005 . 
Journal of Healthcare Technology and Medicine Vol. 6 No. 2 Oktober 2020

Universitas Ubudiyah Indonesia

e-ISSN : 2615-109X

Tujuan penelitian ini untuk mengetahui ektivitas ekstrak bunga melati (Jasminum sambac L.) terhadap daya bunuh larva nyamuk Aedes Aegypti.

\section{METODE PENELITIAN}

Dalam penelitian ini peneliti menggunakan metode quasi eksperimen dengan desain Post Only Control Group. Uji yang digunakan dlam penelitian ini yaitu uji One way annova, uji Post hoc test dan uji kolerasi. Penelitian ini hanya membahas tentang kemampuan konsentrasi ekstrak Jasminum Sambac L dalam pengendalian larva nyamuk Aedes aegypti yang memiliki unsur larvasida yaitu, saponin, tannin, flavonoid, dan alkaloid.

Populasi dalam sampel ini adalah larva nyamuk Aedes aegypti. Larva nyamuk Aedes aegypti digunakan karena habitat nyamuk Aedes aegypti sendiri berada disekitar lingkungan manusia maka mudah untuk didapatkan dibandingkan jenis nyamuk yang lain.

Untuk kelompok perlakuan, konsentrasi yang dipakai sebanyak 5 konsentrasi yaitu: $0,01 \%, 0,02 \%, 0,03 \%, 0,04 \%$, dan $0,05 \%$, sedangkan untuk kelompok kontrol ada 2 yaitu aquades (sebagai kontrol negative) dan abate (sebagai kontrol positif). Penelitian ini dilakukan di Laboratorium STIKes Harapan Ibu Jambi dan larva Aedes aegypti di identifikasi di Laboratorium Politeknik Kesehatan Lingkungan Kota Jambi, waktu penelitian di laksanakan mulai bulan Mei sampai Juni tahun 2020.

\section{HASIL DAN PEMBAHASAN}

Hasil penelitian menunjukkan rata-rata kematian larva pada konsentrasi 0,01 adalah $57,0 \%$, rata-rata kematian larva pada kosentrasi 0,02 adalah $66 \%$, rata-rata kematian larva pada konsentrasi 0,03 adalah $75 \%$, rata-rata kematian larva pada kosentrasi 0,04 adalah 90\% dan rata-rata kematian larva pada kosentrasi 0,05 adalah 100\% (tabel 1). Hasil bivariat diketahui pengaruh ekstrak bunga melati (Jasminum Sambac L.) terhadap kematian larva nyamuk Aedes Aegypti $(\mathrm{p}=0,000)$ (Tabel 2). 
Journal of Healthcare Technology and Medicine Vol. 6 No. 2 Oktober 2020

Universitas Ubudiyah Indonesia

e-ISSN : 2615-109X

Tabel 1. Rata-rata hasil pengamatan Jumlah Larva Aedes Aegypti yang Mati Akibat Pemberian Ekstrak Bunga Melati (Jasminum Sambac L)

\begin{tabular}{|c|c|c|c|c|c|c|c|c|c|}
\hline \multirow{2}{*}{ No } & \multirow{2}{*}{$\begin{array}{c}\text { Konsentrasi } \\
(\%)\end{array}$} & \multirow{2}{*}{$\begin{array}{l}\text { Jumlah } \\
\text { Larva uji }\end{array}$} & \multicolumn{5}{|c|}{$\begin{array}{l}\text { Jumlah Kematian Larva } \\
\text { pada Tiap Pengulangan }\end{array}$} & \multicolumn{2}{|c|}{ Rata-rata } \\
\hline & & & 1 & 2 & 3 & 4 & 5 & $\begin{array}{c}\text { Kematian } \\
\text { Larva }\end{array}$ & $\%$ \\
\hline 1 & $\begin{array}{l}\text { Kontrol (-) } \\
\text { : Aquades }\end{array}$ & 20 & 0 & 0 & 0 & 0 & 0 & 0 & 0 \\
\hline 2 & $0,01 \%$ & 20 & 10 & 12 & 13 & 10 & 12 & 11,4 & $57,0 \%$ \\
\hline 3 & $0,02 \%$ & 20 & 13 & 12 & 14 & 13 & 14 & 13,2 & $66,0 \%$ \\
\hline 4 & $0,03 \%$ & 20 & 14 & 15 & 14 & 16 & 16 & 15 & $75,0 \%$ \\
\hline 5 & $0,04 \%$ & 20 & 17 & 17 & 18 & 19 & 19 & 18 & $90,0 \%$ \\
\hline 6 & $0,05 \%$ & 20 & 20 & 20 & 20 & 20 & 20 & 20 & $100 \%$ \\
\hline 7 & $\begin{array}{l}\text { Kontrol }(+) \\
\text { : Abate }\end{array}$ & 20 & 20 & 20 & 20 & 20 & 20 & 20 & $100 \%$ \\
\hline
\end{tabular}

Tabel 2. Hasil Uji One Way Anova

\begin{tabular}{cccc}
\hline Konsentrasi & Mean & SD & P-Value \\
\hline $0,01 \%$ & 11,40 & 1,342 & 0,000 \\
$0,02 \%$ & 13,20 & 0,837 & \\
$0,03 \%$ & 15,00 & 1,000 & \\
$0,04 \%$ & 18,00 & 1,000 & \\
$0,05 \%$ & 20,00 & 0,00 & \\
Kontrol (+) Abate & 20,00 & 0,00 & \\
\hline
\end{tabular}

Rata-rata jumlah kematian larva Aedes aegypti pada konsentrasi 0,01\% adalah 11,4 dengan standar deviasi 1,324, konsentrasi 0,02\% adalah 13,2 dengan standar deviasi 0,837 , konsentrasi $0,03 \%$ adalah 15,0 dengan standar deviasi 1,00 , konsentrasi $0,04 \%$ adalah 18,0 dengan standar deviasi 1,00, Sedangkan pada konsentrasi $0,05 \%$ adalah 20,00 dengan standar deviasi 0,000 dan untuk kelompok control (+) abate adalah 20,00 dengan standar deviasi 0,000.

Hasil uji statistik didapat nilai $\mathrm{p}$-value $=0,000(\mathrm{p}<0,05)$, sehingga Ho ditolak dengan arti ada perbedaan rata-rata diantara 5 konsentrasi ekstrak bunga melati. Penelitian ini dilakukan untuk mengetahui apakah ekstrak bunga melati memiliki pengaruh terhadap larva Aedes aegypti. Pada kelompok kontrol larva uji di berikan 2 perlakuan yaitu kontrol positif (abate) dan kontrol negative (aquades). 
Journal of Healthcare Technology and Medicine Vol. 6 No. 2 Oktober 2020

Universitas Ubudiyah Indonesia

e-ISSN : 2615-109X

Sebagai kontrol negative yaitu aquades (tanpa zat), hasil uji menunjukkan pada kontrol negative tidak terjadi kematian larva Aedes aegypti. Kontrol positif yaitu bubuk abate hasil uji menunjukkan kematian 100\% larva aedes aegypti pada jam ke 6 pengujian. Uji aktivitas kontrol positif dengan menggunakan bubuk abate dalam membunuh larva Aedes aegypti lebih efektif dibandingkan dengan ekstrak bunga melati (Jasminum Sambac L), akan tetapi ekstrak bunga melati tidak berbahaya bagi manusia.

Dari hasil penelitian didapatkan 4 senyawa dalam ekstrak tersebut, yaitu saponin, tannin, alkaloid, dan flavonoid. Saponin dapat menyebabkan korosi dinding traktus digestivus larva dikarenakan kemampuan saponin merusak membrane. Saponin juga dapat mengganggu lapisan lipoid pada epikutikula dan lapisan protein pada endokutikula sehingga memudahkan zat toksik masuk kedalam tubuh larva. Tannin merupakan phonelic compounds yang dapat mempresipitasi protein. Tannin memiliki kemampuan untuk mempresipitasi protein yang di perlukan larva untuk pertumbuhan, sehingga dapat menyebabkan larva mati. Senyawa alkaloid berperan sebagai larvasida dengan cara menghambat daya makan larva (antifeedant), sehingga larva akan menngalami kekurangan nutrisi dan pada akhirnya mati. Senyawa flavonoid yang terkandung dalam ekstrak bunga melati juga bersifat insektisida karena merupakan racun pernapasan sehingga menyebabkan larva tidak bisa bernapas karena kerusakan sistem pernapasan dan akhirnya menyebabkan kematian larva (Musiam, 2018).

Pada penelitian ini pemilihan umur larva merupakan hal penting karena larva tersebut menjadi objek dalam penelitian ini. Jika salah memilih umur akan dapat mengakibatkan tingkat kematian larva terlalu cepat sehingga akan di dapatkan hasil angka yang kurang mewakili. Pada penelitian ini dipilih larva yang tidak terlalu kecil yaitu larva instrar III sehingga mudah untuk diamati dan larva tersebut merupakan bentuk larva yang aktif dalam mencari makan. Larva nyamuk Aedes aegypti di dapat dari pemasangan ovitrap dan sebagian di dapat dari genangan air dari drum rumah warga. Larva Aedes aegypti di ambil 2 hari sebelum pengujian dengan menggunakan gelas plastic agar mempermudah saat pengambilan. Sedangkan pemasangan ovitrap dilakukan seminggu sebelum dilakukan pengujian. 
Journal of Healthcare Technology and Medicine Vol. 6 No. 2 Oktober 2020

Universitas Ubudiyah Indonesia

e-ISSN : 2615-109X

Hasil penelitian yang dilakukan oleh Dwi Rahayu (2007) tentang uji aktivitas larvasida minyak atsiri bunga melati (jasminum sambac (l.)ait) terhadap daya bunuh larva nyamuk aedes aegipty instar III diperoleh hasil bahwa pemberian minyak atsiri bunga melati (Jasminum sambac (L.)ait) dengan konsentrasi yang berbeda berpengaruh sangat nyata terhadap kematian larva nyamuk Aedes aegypti instar III, sedangkan konsentrasi yang efektif membunuh larva adalah $0,9999 \mu \ell / 100 \mathrm{ml}$ air dalam 24 jam karena mampu membunuh 100\% larva.

Berdasarkan hasil uji korelasi diperoleh nilai $\mathrm{p}=0,000$, sehingga dapat disimpulkan bahwa ada pengaruh ekstrak bunga melati terhadap kematian larva Aedes aegypty. Selain itu juga diperoleh nilai $\mathrm{R}=0,961$ yang menunjukkan hubungan kuat. Semakin tinggi konsentrasi ekstrak yang diberikan maka semakin banyak pula kandungan saponin, tannin, flavonoid,dan alkaloid yang diterima atau kontak langsung dengan larva pada media penelitian dan menyebabkan kematian larva Aedes aegypti.

Hasil penelitian menunjukkan bahwa pada konsentrasi $0,01 \%$ selama 24 jam, kematian larva rata-rata berjumlah 12 (57\% membunuh) yang hidup berjumlah 8 larva dan belum mampu membunuh larva Aedes aegypti. Hal ini ditunjukkan dengan dengan masih adanya gerakan pada larva yang terdapat pada tabung. Pada konsentrasi 0,05\% kematian larva berjumlah 20 larva (100\% membunuh). Hal ini karena semakin pekat konsentrasi larutan maka semakin banyak senyawa metabolik sekunder ekstrak bunga melati (Jasminum sambac L.) yang terkandung dalam larutan, yang berarti semakin banyak pula racun yang dikonsumsi larva Aedes aegypti, sehingga kematianya semakin tinggi.

Uji ekstrak bunga melati (Jasminum sambac L.) sebagai larvasida Aedes aegypti mampu dijadikan sebagai larvasida alami pada Aedes aegypti. Hal ini diharapkan dengan hasil penelitian ekstrak bunga melati (Jasminum sambac L.) nantinya dapat sebagai informasi dan salah satu cara untuk mengurangi perkembangan larva Aedes aegypti yang merupakan vektor virus Flaviridae demam berdarah dengue (DBD). Larvasida alami merupakan larvasida yang dibuat dari tanaman yang mempunyai kandungan senyawa racun terhadap serangga pada stadium larva. Kandungan zat-zat yang terdapat dalam tanaman 
Journal of Healthcare Technology and Medicine Vol. 6 No. 2 Oktober 2020

Universitas Ubudiyah Indonesia

e-ISSN : 2615-109X

yang digunakan sebagai insektisida dari larvasida alami relatif lebih aman dan mempunyai efek samping yang lebih kecil bagi manusia.

\section{KESIMPULAN}

Adanya hubungan konsentrasi $0,01 \%, 0,02 \%, 0,03 \%, 0,04 \%$ dan $0,05 \%$ ekstrak bunga melati terhadap kematian larva Aedes aegypti, dimana rata-rata jumlah larva Aedes aegypti yang mati untuk setiap konsentrasi mengalami peningkatan, semakin besar konsentrasi yang di pakai untuk perlakuan semakin banyak jumlah larva yang mati. Selain itu juga, yang menunjukkan efektif adalah 0,05\%, karena konsentrai $0,05 \%$ sudah dapat membunuh larva Aedes aegypti $100 \%$ dalam waktu 24 jam

\section{SARAN}

1. Dapat diaplikasikan kepada masyarakat sebagai salah satu alternatif insektisida alami terhadap mortalitas larva aedes sp misal sebagai pengendalian hayati Aedes sp

2. Bagi instansi kesehatan agar mendukung penggunaan larvasida alami sehingga ditemukan larvasida alami pengganti abate (temephos).

3. Bagi peneliti selanjutnya Perlu ada penelitian lebih lanjut untuk membuat formulasi yang baik sehingga dapat digunakan di masyarakat sebagai larvarsida yang mudah, murah dan aman.

\section{DAFTAR PUSTAKA}

Dinkes Kota Jambi. 2019. Profil Kesehatan Kota Jambi Tahun 2018. Jambi: Dinkes Kota Jambi

Dwi R. 2007. Uji Aktivitas larvasida minyak atsiri bunga melati (Jasminum Sambac (L.)ait)terhadap daya bunuh larva nyamuk Aedes eegypti instar III. Surakarta; 2007.

Kemenkes RI. 2019. Profil Kesehatan Indonesia Tahun 2018. Jakarta: Kemenkes RI

Lyaningsih. 2004. Toksikologi Dasar. Jakarta: Universitas Indonesia Press. 
Journal of Healthcare Technology and Medicine Vol. 6 No. 2 Oktober 2020

Universitas Ubudiyah Indonesia

e-ISSN : 2615-109X

Musiam, S. 2018. Uji biolarvasida Ekstrak Methanol Daun Jeruk Nipis (Citrus Aurantifoloa) Terhadap Nyamuk Aedes Aegypti L. Jurnal Ilmiah Ibnu Sina. Vol.3, no. 1, 55-63

Nurdianti, D. 2014. Keefektifan Daya Bunuh Minyak Atsiri Bunga Kenanga (Cannangium odoratum) Terhadap Kematian Larva Nyamuk Aedes aegypti Instar III. Skripsi thesis, Universitas Muhammadiyah Surakarta

World Health Organization. 2014. Dengue Guidelines For Diagnosis, Treatment, Prevention and Control

Sumantri, A. 2010. Kesehatan Lingkungan Edisi Revisi. Jakarta: Kencana. 